\title{
Occupational Stress, Job Satisfaction \& Mental Health among Employees of Government and Non-government Sectors
}

\author{
Kapildev S. Khudaniya*, Dr. S. M. Kaji**
}

\section{ABSTRACT:}

The purpose of the present study was to compare occupational stress, job satisfaction \& mental health among employees of government and non-government sectors. In the present study the data was collected from government and non-government sectors (schools, colleges, companies \& banks). A sample of 100 employees (50 government employees and 50 non-government employees) was selected randomly. The sample was equally distributed as per the gender. For this purpose of investigation "Occupational Stress Index" develop by Dr. A.K.Srivastava \& Dr. A.P.Singh , Job Satisfaction Scale develop by Dr.Amar Singh \& Dr. T.R.Sharma , and Employee's Mental Health Inventory develop by Dr. Jagdish were used. Data was analyzed using Mean's, SD's and t values. The finding showed that there is no significant difference in occupational stress, job satisfaction and mental health with respect to both sectors and gender. Result also showed that job satisfaction and mental health $(0.149)$ dimensions were found positively correlated and job satisfaction (-0.186) and mental health $(-0.108)$ were found negatively correlated with occupational stress.

Keywords: occupational stress, job satisfaction, mental health, government, non-government, employees

\section{INTRODUCTION}

Occupational stress is stress involving work. According to the current World Health Organization's (WHO) definition, “Occupation or work related stress's the response people may have when presented with work demands and pressures that are not matched to their knowledge and abilities and which challenge their ability to cope". Occupational stress nearly every one agrees that occupational stress results from the interaction of the worker and their conditions of work.

*Ph.D. Scholar, Gujarat University, Ahmadabad, Gujarat

**Associate Prof. Department of psychology, L.D. Arts College, Ahmadabad-Gujarat

(C) 2014 K Kudaniya, S Kaji; licensee IJIP. This is an Open Access Research distributed under the terms of the Creative Commons Attribution License (http://creativecommons.org/licenses/by/2.0), which permits unrestricted use, distribution, and reproduction in any Medium, provided the original work is properly cited. 


\section{Occupational Stress, Job Satisfaction \& Mental Health among Employees of Government and Non- government Sectors}

"Looking after one's mind is as important as looking after one's body"? as part of one's overall health, mental and emotional health or well being is a necessary condition to enable one to manage one's life successfully. Mental health is the emotional and spiritual resilience that allow one to enjoy life and to survive pain, suffering and disappointment, it is a positive sense of well being and a underlying belief is one's own and others dignity and worth.

Mental health is about how a person thinks feels and acts when faced with life's situations. Mental health is how people look at themselves, their lives, and the other people in their lives, evaluate their challenges and problems, and explore choices. This includes handling stress, relating to their people, and making decisions.

Job satisfaction is on attitude that employees have about their work and based on numerous factors, both intrinsic and extrinsic to the individuals. Job satisfaction is important from the retaining the appropriate employees within the organization: it is about fitting the right person to the right job in the right culture and keeping them satisfied.

L. NAHAR ET AL. (2013 investigated relationship of job satisfaction, job stress and mental health on government and non-government employees. And found job satisfaction among male employees was better than female employees but job stress and mental health found equal in both sex. Non government employees found to feel more job stress than government employees. But in job satisfaction and mental health both are equal. And mental health for the Government employee is little bit higher than non-government employee and also by sex job stress and mental health and sex was a negative relationship, but not significant.

Dr. Beulah Viji Christiana. M, \& Dr. Mahalakshmi, V. (2013) Role Stress and its Impact on Public and Private Sector Managers in Chennai: An Empirical Study and found, there is no significant difference in the stress experienced by both the public and private sector managers certain individual stressors such as work experience and educational qualifications yield differences D'Aleo, Stebbins, Lowe, Lees, and Ham (2007) examine a sample of 559 public and 105 private sector employees to assess their respective risk profiles. They find that public sector employees face more stress than private sector employees. Malik (2011) collects data on 200 bank employees in Quetta, Pakistan, of which 100 work in public sector banks and the remaining 100 in private sector banks. The author finds that there is a significant difference in the level of stress to which both groups are subject, and that public sector bank employees face a high level of occupational stress. Bushara Bano and Rajiv Kumar Jha (2012), The aim of this study is to explore the differences in job-related stress, if any, between public and private sector employees, based on ten role stressors and found both public and private sector employees face moderate levels of stress. While there is no significant difference overall between public and private sector employees in terms of total stress levels, certain individual stressors - such as work experience and educational qualifications — do yield differences. 


\section{Occupational Stress, Job Satisfaction \& Mental Health among Employees of Government and Non- government Sectors}

Abu Baker Almintisir, Abu Baker Akeel and Indra Devi Subramaniam (2012),Comparison of Job Satisfaction of Employees in Public and Private Sector Organizations: Evidence from Two Libyan Companies job satisfaction of private sector company employees is significantly higher than that of government company employees. In addition from the response of the employees from the two sector to the statement " all things considered I am very satisfied with my job" it can be seen that the private sector employees are significantly more satisfied with their jobs compared to employees from the government company $(X 2=92.95, \mathrm{p}<0.05)$

Alam, S.\& Rizvi, K (2012) psychological well-being among bank employees and found psychological well-being is higher in public sector as compared to their counterparts in private sector bank.

Lehal (2007), Studied Job Satisfaction and Organisational Role Stress in employees in Punjab and found a negative correlation between Organisational role stress and job satisfaction.

Nasurdin, Aizzat Mohd Ramayah, T Kumaresan, S (2005) in their study tried to identify the influence of organizational variables (conflict, blocked career, alienation, work over load, and unfavorable work environment) on job stress among managers and to examine whether this relationship varies according to the individual's level of neuroticism. The results of the study conveyed the fact that neuroticism was found to moderate the effects of the three organizational stressors (alienation, work overload, and unfavorable work environment) on job stress.

A. Khetarpal \& G. Kochar(2006) in their study attempted to provide a preventive and positive approach to women experiencing stress at work and at home. to find out the level of role stress and to identify key role stressors, the OSI inventory by A. Krivastava was used. It was found that majority of women were under moderately low level of stress. The key stressors which affect Maximum numbers of women are Poor Peer Relations, Intrinsic Impoverishment and Underparticipation.

A study conducted by LeRouge, et al (2006) concluded that role stress was positively related to both job satisfaction and organizational commitment and that self-esteem significantly moderated the relationship between role stress fit and job satisfaction.

Lewig and Dollard (2001) find that public sector employees are subject to greater work-related stress than private sector employees. Dollard and Walsh (1999), however, report that private sector workers in Queensland, Australia, had made twice as many stress claims as public sector workers. Macklin et al. (2006) survey 84 public and 143 private sector employees to assess any significant difference in their stress levels. They conclude that there is no significant difference between employees on the basis of sector, but that there is a significant difference between genders, i.e., female employees are subject to greater stress than males.

\section{OBJECTIVES}

1 To study and compare occupational stress, job satisfaction and mental health between employees of government and non-government sectors. 
2 To study and compare occupational stress, job satisfaction and mental health between male and female employees

3 To study of correlation between Occupational stress, Job Satisfaction and Mental Health on employees of government and non-government sectors

\section{HYPOTHESIS}

1. There is no significant difference among type of sectors and gender with regards to their occupational stress, job satisfaction and mental health.

2. There is no significant correlation between occupational stress, job satisfaction and mental health on employees of government and non-government sectors.

\section{METHODOLOGY}

\section{Sample}

In the present study, sample was consisted of 100 employee in which 50 government sectors (25 males \& 25 females) and 50 non -government sectors ( 25 males \& 25 females) were selected randomly.

\section{Design}

\begin{tabular}{lccc}
\hline Variable & Government sector & $\begin{array}{c}\text { Non -government } \\
\text { Sector }\end{array}$ & Total \\
\hline Male & 25 & 25 & 50 \\
Female & 25 & 25 & 50 \\
\hline Total & 50 & 50 & 100 \\
\hline
\end{tabular}

\section{Tools:}

Occupation stress index The Occupational Stress index (OSI) developed by Dr A.K.Srivatava and Dr. A.P. Singh was used for the study. The scale consisted of forty six items, each to rated on the five-point scale. Out of 46 items, 28 are "true keyed" and the balance 18 is "false keyed". The items related to almost all relevant components of the job life which causes stress in some way or the other such as role- overload, role-ambiguity, role conflict, group and political 


\section{Occupational Stress, Job Satisfaction \& Mental Health among Employees of Government and Non- government Sectors}

pressure, responsibility for persons, under participation, powerlessness, poor peer relationship, intrinsic impoverishment, low status, strenuous working conditions and unprofitability. The reliability index ascertained by split half(odd-even) method and Cronbach's Alpha Coefficient for the scale as a whole were found to be 0.935 and 0.90 respectively. The validity of the instrument was determined by computing coefficient of correlation between the scale on the OSI and various measures of job attitudes and job behaviour.

Job Satisfaction scale:-The job satisfaction scale developed by Dr. Amar Singh \& Dr. T.R. Sharma was used to measure job satisfaction. The scale has a very wide acceptance in measuring psychological aspects of functioning in any profession. It consisted 30 statements. Each to be related five point scale. The test retest reliability of the scale works out to be 0.978 . The scale compares favourably with Muthayya's job satisfaction questionnaire giving a validity coefficient of 0.743

Employee's mental health:- The Employee's Mental Health Inventory (EMHI) developed by Dr. Jagdish was used for the study. The scale consisted of Twenty items, each has two response alternative, i.e. 'yes' and 'No'. the reliability of the Inventory is Reliability Coefficient 0.66, Reliability Coefficient corrected with Spearman -Brown formula 0.79 and Index of Reliability 0.89 . the Validity of the instrument was determined by computing the coefficient of correlation between the score on EMHI and Mental Health Scale (Buck, 1972) and Personal Adjustment (Pestonjee, 1973). The validity coefficient was found to be 0.74 and 0.57 .

\section{PROCEDURE}

The employees of Government and Non-government sectors were randomly selected \& Occupational Stress Index, Job Satisfaction Scale, and Employees Mental Health Inventory were given $\&$ data was collected . The obtain data was analyzed with help of mean, SD, ' $t$ ' value and correlation. 


\section{Occupational Stress, Job Satisfaction \& Mental Health among Employees of Government and Non- government Sectors}

\section{RESULT \& DISCUSSION}

The statistical methods used to analyze obtained data are Mean, S.D. , ' $t$ ' test and Pearson Product Moment Correlation ' $r$ ' .

\section{Table-1}

Mean, standard deviation and ' $t$ ' test according to Occupational stress for the types of employees/ sectors

\begin{tabular}{llllll}
\hline Types of sector & $\mathrm{N}$ & Mean & $\mathrm{SD}$ & $\mathrm{t}$ & significant \\
\hline Government & 50 & 117.92 & 18.949 & & Non sig. \\
Non-government & 50 & 122.28 & 22.406 & & \\
\hline
\end{tabular}

The table-1, indicates that the mean scores of occupational stress of government and Nongovernment employees are 117.92 and 122.28. the standard deviations for both government and non-government employees are 18.949 and 22.406 respectively. "t" value was found 1.051 which is not significant at 0.05 level. Its indicate that there is no significant difference among employees of government and non-government sector with regard to their Occupational Stress.

Table-2

Mean, standard deviation and ' $t$ ' test according to Occupational stress for the Gender

\begin{tabular}{llllll}
\hline Gender & $\mathrm{N}$ & Mean & $\mathrm{SD}$ & $\mathrm{t}$ & significant \\
\hline Male & 50 & 116.86 & 19.685 & & \\
Female & 50 & 123.34 & 21.496 & & Non sig. \\
\hline
\end{tabular}

The table-2 indicates that the mean scores of occupational stress of male and female employees are 116.86 and 123.34. the standard deviations for both government and non-government employees are 19.685 and 21.496 respectively. " $t$ " value was found 1.572 which is not significant at 0.05 level. Its indicate that there is no significant difference among male and female employees with regard to their Occupational Stress. 


\section{Table-3}

Mean, standard deviation and ' $\mathrm{t}$ ' test according to Job satisfaction for the types of employees/ sectors

\begin{tabular}{lccccc}
\hline Types of sector & $\mathrm{N}$ & Mean & SD & $\mathrm{t}$ & significant \\
\hline Government & 50 & 70.82 & 14.439 & & \\
Non-government & 50 & 74.56 & 12.717 & & Non sig. \\
\hline
\end{tabular}

The table-3, indicates that the mean scores of Job satisfaction stress of government and Nongovernment employees are 70.82 and 74.56. the standard deviations for both government and non-government employees are 14.439 and 12.717 respectively. " $t$ " value was found 1.272 which is not significant at 0.05 level. Its indicate that there is no significant difference among employees of government and non-government sector with regard to their Job satisfaction.

\section{Table-4}

Mean, standard deviation and ' $t$ ' test according to Job satisfaction for the Gender

\begin{tabular}{lccccc}
\hline Gender & $\mathrm{N}$ & Mean & SD & $\mathrm{t}$ & significant \\
\hline Male & 50 & 75.02 & 12.172 & & \\
Female & 50 & 70.36 & 16.731 & & Non sig. \\
\hline
\end{tabular}

The table 4 indicates that the mean scores of Job satisfaction of male female employees are 75.02 and 70.36. the standard deviations for both government and non-government employees are 12.172 and 16.731 respectively. "t" value was found 1.593 which is not significant at 0.05 level. Its indicate that there is no significant difference among male and female employees with regard to their Job satisfaction.

\section{Table-5}

Mean, standard deviation and ' $t$ ' test according to Mental Health for the types of employees/ sectors

\begin{tabular}{lccccc}
\hline Types of sector & $\mathrm{N}$ & Mean & SD & $\mathrm{t}$ & significant \\
\hline Government & 50 & 20.32 & 3.282 & & \\
Non-government & 50 & 21.2 & 2.607 & 1.484 & Non sig. \\
\hline
\end{tabular}

The table $=5$ indicates that the mean scores of mental health of government and Non-government employees are 20.32 and 21.20 the standard deviations for both government and non- 


\section{Occupational Stress, Job Satisfaction \& Mental Health among Employees of Government and Non- government Sectors}

government employees are 3.282 and 2.607 respectively. " $t$ " value was found 1.484 which is not significant at 0.05 level. Its indicate that there is no significant difference among employees of government and non-government sector with regard to their Occupational Stress.

\section{Table-6}

Mean, standard deviation and ' $t$ ' test according to Mental Health for the Gender

\begin{tabular}{lccccc}
\hline Gender & $\mathrm{N}$ & Mean & $\mathrm{SD}$ & $\mathrm{t}$ & significant \\
\hline Male & 50 & 20.94 & 2.595 & & \\
Female & 50 & 20.58 & 3.341 & 0.601 & Non sig. \\
\hline
\end{tabular}

The table-6 indicates that the mean scores of Mental health of male and female employees are 20.94 and 20.58. The standard deviations for both government and non-government employees are 2.595 and 3.341 respectively. "t" value was found 0.601 which is not significant at 0.05 level. Its indicate that there is no significant difference among male and female employees with regard to their Job satisfaction.

\section{Table-7}

Correlation among Occupational stress, job satisfaction, and mental health of employees of government and non-government sectors

\begin{tabular}{lccc}
\hline Variables & $\mathrm{N}$ & Mean & $\mathrm{r}$ \\
\hline occupational stress & 100 & 120.1 & -0.185 \\
Job satisfaction & 100 & 72.69 & \\
\hline occupational stress & 100 & 120.1 & -0.108 \\
mental health & 100 & 20.76 & \\
\hline job satisfaction & 100 & 72.69 & 0.149 \\
mental health & 100 & 20.76 & \\
\hline
\end{tabular}

Table 7 show that there is negative correlation between occupational stress and job satisfaction on employees of government and non-government sectors.. Here also negative correlation between occupational stress and mental health on employees of government and non-government sectors. And there is positive correlation between job satisfaction and mental health on employees of government and non-government sectors, which is very low. 


\section{Occupational Stress, Job Satisfaction \& Mental Health among Employees of Government and Non- government Sectors}

\section{CONCLUSION}

1. There is no significant difference among type of sectors and gender with regards to their occupational stress, job satisfaction and mental health

2. There is occupational stress negatively correlated with job satisfaction and mental health

3. There is positive correlation between job satisfaction and mental health

\section{REFERENCES}

1. Alam, S.\& Rizvi, K (2012), Psychological well-being among bank employees. Journal of the Indian accedemy of applied psychology, vol.38, no.2, 242-247

2. Almintisir A.B ET AL (2012), Comparison of Job Satisfaction of Employees in Public and Private Sector Organizations: Evidence from Two Libyan Companies. Australian Journal of Basic and Applied Sciences, 6(8): 177-186, ISSN 1991-8178

3. Bano,B. and Jha,R.K. (2012),Organizational Role Stress Among Public and Private Sector Employees: A Comparative Study. The Lahore Journal of Business): pp. 23-36

4. Dr. Beulah Viji Christiana. M, Dr. V.Mahalakshmi(2013), Role Stress and its Impact on Public and Private Sector Managers in Chennai: An Empirical Study. Vol. 3, Issue 1, Jan March 2013 ISSN : 2230-9519 (Online) | ISSN : 2231-2463 (Print)

5. Dr. Jagdish(1990), Manual for employee's mental health inventory. Rakhi prakashan, Agra, India

6. Dr. Singh, A. \& Dr. Sharma,T.R. (1990), Manual for job satisfaction scale. National psychological corporation, Agra, India

7. Dr. Srivastava, A.K. \& Dr. Singh, A.P. (1981), Manual of occupational stress index. Manovagyanik parikchhan sansthan, Varansi, India

a. http://www.ripublication.com/ijepa.htm

8. Kaur surinder(2011), Comparative Study of Occupational Stress among Teachers of Private and Govt. Schools in Relation totheir Age, Gender and Teaching Experience. International Journal of Educational Planning \& Administration ISSN 2249-3093 Volume 1, Number 2 (2011), pp. 151-160,@ Research India Publications,

9. L. NAHAR ET AL. (2013, A investigated relationship of job satisfaction, job stress and mental health on government and non-government employees. Psychology 2013. Vol.4, No.6, 520-525, Published Online June 2013 in SciRes (http://www.scirp.org/journal/psych)

10. Lehal, R. (2007), A Study of Organisational Role Stress and Job Satisfaction Among Executives in Punjab. Indian Management Studies Journal, 11, pp. 67-80

11. Macklin, D. S.,ET AL (2006), Public and private sector work stress: Workers' compensation, levels of distress and job satisfaction, and the demand-control-support model. Australian Journal of Psychology, 58(3), 130-143.

12. Malik, N. (2011). A study on occupational stress experienced by private and public sector bank employees in Quetta city. African Journal of Business Management, 5(8), 3063-3070. 